\title{
PATI TERMODIFIKASI ENZIMATIS SEBAGAI KOMPONEN PEREKAT BAHAN SALUT KERTAS CETAK
}

\author{
Nina Elyani, Jenni Rismijana, Teddy Kardiansyah, Cucu \\ Balai Besar Pulp dan Kertas \\ Jl. Raya Dayeuhkolot 132 Bandung 40258, Telp +62225202980, Fax +62225202871 \\ Diterima : 03 Februari 2012, Revisi akhir : 07 Mei 2012
}

\section{ENZYMATIC MODIFIED STARCH AS BINDER COMPONENT OF COATING COLOR FOR COATED PRINTING PAPER}

\begin{abstract}
This research has been conducted through several steps. Step I was base papermaking using $80 \%$ LBKP and $20 \%$ NBKP. They were refine separately up to $300 \mathrm{ml} C S F$, then mixed with $15 \%$ CaCO3, $0.6 \%$ AKD , 0.5\% poliacrylamide, and 1,5\% cationic starch to dry-weight of fibers. Step II was modifying starch enzymaticaly at $70-75^{\circ} \mathrm{C}, \mathrm{pH} 6.5-7.0$, amylase $0,05 \%$ for 15 minutes. Step III was base-paper coating with varied adhesives. Variation I use natural starch, Variation II use enzymatic modified starch, Variation III use commercial starch each of 8\%. Testing for the handsheets comprise of brightness, roughtness, picking strength, water penetration, and $\mathrm{pH}$. The results showed that the viscosity for natural starch, enzymatic starch and commercial starch respectively at $8000 \mathrm{cPs}, 26 \mathrm{cPs}$ and 114 cPs. The use of enzymatic modified starch give the best paper properties. The experiments has replicated in a laboratory of paper industry, with the same results, using clay and CaCO3 at 40:60 ratio, enzymatic starch, commercial starch, and natural starch.
\end{abstract}

Keywords: starch, coated printing paper, amylase, viscosity.

\begin{abstract}
ABSTRAK
Penelitian ini dilakukan melalui beberapa tahapan. Tahap I adalah pembuatan kertas dasar dengan menggunakan bahan baku 80\% serat pendek atau leaf bleached kraft pulp (LBKP) dan 20\% serat panjang atau needle bleached kraft pulp ( NBKP) digiling secara terpisah hingga mencapai derajat giling $300 \mathrm{ml}$ CSF. Selanjutnya pulp dicampur ke dalam bahan kimia yang terdiri $15 \% \mathrm{CaCO}_{3}, 0,6 \%$ AKD , $1,5 \%$ pati kationik dan Poliakrilamida sebesar $0,5 \%$ terhadap berat kering pulp. Lembaran dibuat pada gramatur $60 \mathrm{~g} / \mathrm{m}^{2}$. Tahap II adalah pembuatan pati termodifikasi enzimatis pada kondisi inkubasi suhu sekitar $70-75^{\circ} \mathrm{C}, \mathrm{pH}: 6,5-7,0$, waktu selama 15 menit dengan penambahan amilase sebesar $0,05 \%$. Tahap III adalah proses penyalutan kertas dasar dengan pati termodifikasi enzimatis, sebagai pembanding menggunakan pati alam maupun pati komersial. Kemudian dilakukan pengujian terhadap lembaran yang dihasilkan meliputi : derajat putih, kekasaran, penetrasi minyak, ketahanan cabut, daya serap air dan $\mathrm{pH}$. Selanjutnya dilakukan uji coba di industri dengan komposisi pigmen kaolin dan kalsium karbonat 40 : 60 menggunakan pati enzim, pati komersial, dan pati alam. Hasil percobaan menunjukkan bahwa viskositas untuk pati alam, pati enzim dan pati komersial masing-masing adalah sebasar 8000 cPs, 26 cPs dan 114 cPs. Penggunaan pati modifikasi enzim memberikan sifat kertas yang paling baik. Hasil replikasi percobaan di laboratorium industri, pati enzim juga menghasilkan sifat kertas yang lebih baik.
\end{abstract}

Kata kunci: pati, kertas cetak salut, amilase, viskositas. 


\section{PENDAHULUAN}

Kertas cetak salut merupakan sejenis kertas cetak yang dibuat dari pulp kimia, dapat dicampur dengan pulp mekanis maksimum 15\%. Mempunyai sifat cetak yang baik, kelicinan, opasitas dan kilap yang tinggi. Dilakukan proses pengerjaan akhir disalut satu atau keduanya dan juga dilakukan proses super kalender. Kertas cetak salut ini umumnya digunakan untuk keperluan mencetak kalender, majalah, kulit buku dan lainlainnya. Proses pembuatan kertas cetak salut dilakukan melalui proses pembuatan kertas dasar kemudian dilanjutkan dengan penyediaan bahan salut, pembuatan campuran salut dan proses penyalutan.

Kualitas kertas salut sangat dipengaruhi oleh kertas dasarnya, sifat-sifat kertas dasar yang terpenting antara lain keseragaman lembaran, porositas, sifat kekuatan fisik lembaran, kadar air, derajat putih, opasitas dan kelicinan (Y V Sood dkk, 2010). Selain itu perlu diperhatikan juga komponen campuran salutnya, seperti pigmen, perekat dan aditif. Pigmen merupakan komponen utama dalam bahan salut, umumnya digunakan antara $70-90 \%$ dari total campuran salut. Jenis pigmen yang umum digunakan adalah: kaolin, kalsium karbonat, titanium oksida dan satin white (Lehtinen,2000 and Mueller, 2005). Sedangkan perekat yang umum digunakan terdiri dari : pati, casein, styrene-butadiene rabber, acrylic, PVA dan PVAC yang umumnya sebagian masih impor. Perekat mempunyai pengaruh yang besar pada sifat campuran salut dan sifat akhir kertas cetak salut. Pemakaian perekat harus disesuaikan dengan pigmen yang digunakan, supaya dapat menghasilkan campuran salut dengan keseimbangan atau stabilitas koloid yang tinggi, sehingga sifat campuran salut tidak berubah selama proses (Ragnarsson, 2008).

Fungsi penambahan perekat dapat bertindak sebagai pembawa pigmen, mengikat partikelpartikel pigmen menjadi satu dan mengikat partikel pigmen dengan kertas dasar, memberi sifat alir yang dibutuhkan dan retensi air dari campuran salut dan untuk mengontrol absorpsi tinta cetak selama proses cetak pada kertas (Lehtinen, 2000).

Pada umumnya di industri kertas, pati yang digunakan adalah pati yang dimodifikasi secara kimia yang menghasilkan viskositas larutan pati relatif masih tinggi sehingga distribusi pada lembaran tidak merata yang mengakibatkan perekatan pigmen dengan kertas dasar kurang merata. Pada penelitian pembuatan pati termodifikasi enzimatis, diharapkan nilai viskositas larutan pati yang diperoleh lebih kecil sehingga dapat terdispersi dan terdistribusi pada kertas dasar dengan merata dan dapat menghasilkan lembaran kertas salut yang baik kualitasnya.

Penelitian ini mencoba mengaplikasikan penggunanan pati sebagai perekat alam yang dimodifikasi secara enzimatis (alpha amylase) baik dalam skala laboratorium di BBPK maupun replikasi percobaan di laboratorium industri kertas, kemudian dibandingkan dengan pati alam tanpa dimodifikasi dan pati impor (komersial). Diharapkan dengan menggunakan pati alam yang dimodifikasi secara enzimatis dapat meningkatkan kualitas lembaran kertas salut yang dihasilkan. Lingkup penelitian terdiri dari pembuatan kertas dasar, pembuatan pati termodifikasi enzimatis dan proses penyalutan pada kertas sekala laboratorium, baik di Balai Besar Pulp dan Kertas maupun di Industri Kertas.

\section{BAHAN DAN METODE}

Penelitian dilaksanakan dengan melakukan percobaan di Laboratorium Balai Besar Pulp dan Kertas dan di laboratorium industri kertas di Bandung, meliputi beberapa tahapan yaitu pembuatan kertas dasar, pembuatan pati termodifikasi enzimatis, proses penyalutan dan pengujiaan lembaran kertas salut yang dihasilkan.

\section{Bahan}

Bahan-bahan yang digunakan dalam penelitiian ini adalah serat pendek atau leaf bleached kraft pulp (LBKP), serat panjang atau needle bleached kraft pulp (NBKP), alkyl ketene dimer (AKD), kalsium karbonat $\left(\mathrm{CaCO}_{3}\right)$, pati alam, pati kationik, polyakryl amida, kaolin, latex, pati modifikasi enzim, pati komersil dan PVA (Polyvinyl alcohol), dispersant, lubricant, defomer, insolubilizer dan biocide.

\section{Peralatan}

Peralatan yang digunakan pada penelitian terdiri dari neraca analitik, oven, cawan, desikator, gelas ukur, gelas kimia, niagara beater dan Freenes Tester, $\mathrm{pH}$ meter, termometer, pemanas, agitator dan viskometer brookfield 
untuk pengujian viskositas, proofer coater, pelat pengering, penjepit, dan peralatan untuk pengujiaan lembaran yang dihasilkan seperti : photovolt, bendtsen dan IGT tester.

\section{Metode Penelitian}

Metoda penelitian terdiri dari tahapan kegiatan yaitu :

\section{Pembuatan kertas dasar}

Pulp serat panjang dan pulp serat pendek masing-masing digiling dengan menggunakan beater sampai derajat giling sekitar $300 \mathrm{~mL}$ CSF. Kemudian ditambahkan aditif yang terdiri dari: $15 \%$ kalsium karbonat, $0,6 \%$ AKD, 1,5\% pati kationik dan $0,5 \%$ poliakrilamida masing-masing penambahan bahan kimia berdasarkan berat kering pulpnya. Kemudiaan dibuat lembaran dengan gramatur sekitar $60 \mathrm{~g} / \mathrm{m}^{2}$, di press dan dikeringkan. Lembaran yang dihasilkan sebagai kertas dasar salut. Diagram alir proses pembuatan kertas dasar dapat dilihat pada Gambar 1.

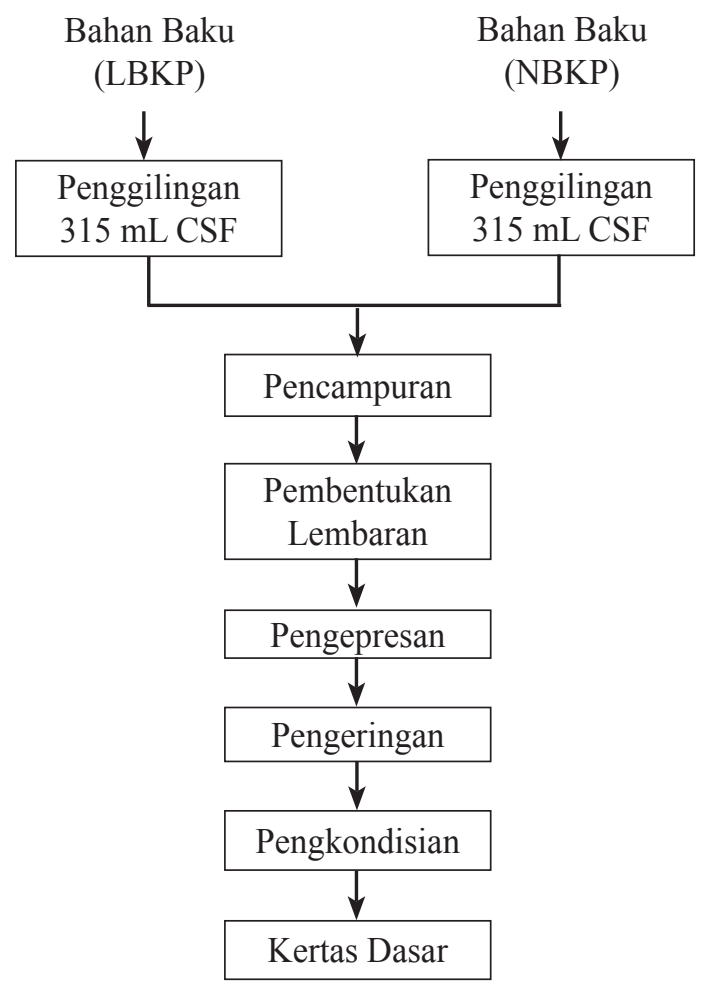

Gambar 1. Diagram Alir Proses Pembuatan Kertas Dasar
2. Pembuatan beberapa jenis pati terdiri dari :

- Pati alam

Dibuat dengan cara menimbang pati yang akan dimasak sebanyak 25 gram/100 mL. Pati dimasukkan sedikit demi sedikit ke dalam gelas kimia yang berisi air sambil diaduk, kemudian dipanaskan selama \pm 30 menit dengan suhu $70^{\circ}-80^{\circ} \mathrm{C}$ lalu didinginkan dan diuji viskositasnya.

- Pati termodifikasi enzimatis

Dibuat dengan cara menimbang 25 gram/100 mL.Pati dimasukkan sedikit demi sedikit ke dalam gelas kimia yang berisi air sambil diaduk, lalu ditambahkan enzim $0,05 \%$. Kemudian campuran dimasak pada suhu $70^{\circ}-75^{\circ} \mathrm{C}$. Setelah mencapai suhu $\pm 75^{\circ} \mathrm{C}$ atau setelah larutan pati matang, dipanaskan dan dibiarkan selama 15 menit pada suhu konstan $75^{\circ} \mathrm{C}$. Kemudian suhu ditingkatkan sampai $90^{\circ} \mathrm{C}$ selama 5 menit untuk menghentikan reaksi enzim. Setelah itu didinginkan dan diuji viskositasnya.

\section{- Pati komersial}

Dibuat dengan cara menimbang pati yang akan dimasak sebanyak 25 gram/100 mL. Pati dimasukkan sedikit demi sedikit ke dalam gelas kimia yang berisi air sambil diaduk, kemudian dipanaskan selama \pm 30 menit dengan suhu $70^{\circ}-80^{\circ} \mathrm{C}$ lalu didinginkan dan diuji viskositasnya.

3. Proses pembuatan campuran salut dan penyalutan lembaran pada kertas dasar

Langkah pertama dalam pembuatan campuran yaitu dispersan dilarutkan dengan air. Setelah larutan terdispersi dengan baik ditambahkan pigmen kering, yaitu $\mathrm{CaCO}_{3}$ dan kaolin sedikit demi sedikit. Kemudian ditambahkan lateks, PVA dan pati (lihat Tabel. 1), kandungan padatan campuran bahan salut sebesar $50 \%$, campuran bahan salut diaduk dengan menggunakan agitator. Pengadukan dilakukan selama 30 menit, kemudiaan dilakukan proses penyalutan dengan cara menuangkan bahan salut kepada kertas dasar lalu diratakan dengan menggunakan proofer coater. Pada penelitian ini kertas dasar yang akan disalut adalah pada satu sisi dengan volume campuran salut masing-masing sebanyak $10 \mathrm{~mL}$. Hasil lembaran kertas yang sudah disalut dikeringkan pada suhu kamar selama 24 jam. 
Tabel 1. Komposisi Campuran Salut

\begin{tabular}{lccc}
\hline \multicolumn{1}{c}{$\begin{array}{c}\text { Bahan } \\
\text { Bag/100 bag pigmen }\end{array}$} & $\begin{array}{c}\text { Variasi I } \\
(\%)\end{array}$ & $\begin{array}{c}\text { Variasi II } \\
(\%)\end{array}$ & $\begin{array}{c}\text { Variasi III } \\
(\%)\end{array}$ \\
\hline $\mathrm{CaCO}_{3}$ & 60 & 60 & 60 \\
Kaolin & 40 & 40 & 40 \\
Latex & 8 & 8 & 8 \\
PVA & 5 & 5 & 5 \\
Pati alam & 8 & - & - \\
Pati modifikasi enzim & - & 8 & - \\
Pati komersil & - & - & 8 \\
Dispersant & 0,4 & 0,4 & 0,4 \\
Antifoam & 0,01 & 0,01 & 0,01 \\
Biocide & 0,01 & 0,01 & 0,01 \\
Insolubilizer & 0,01 & 0,01 & 0,01 \\
Lubricant & 0,01 & 0,01 & 0,01 \\
\hline
\end{tabular}

\section{Pengujiaan kertas salut}

Lembaran kertas yang telah mengalami proses penyalutan, dikondisikan dalam ruangan kondisi selama 24 jam dengan suhu $23 \pm 1{ }^{\circ} \mathrm{C}$ dan RH 50 $\pm 2 \%$. Parameter yang diuji terdiri dari derajat putih, kekasaran, penetrasi minyak, ketahanan cabut, daya serap air $\left(\mathrm{Coob}_{60}\right)$ dan $\mathrm{pH}$.

5. Aplikasi pati termodifikasi enzimatis di industri kertas

Hasil pati modifikasi oleh enzim yang diperoleh dari penelitiaan di Balai Besar Pulp dan Kertas (BBPK) diaplikasikan di industri kertas pada skala laboratorium dengan menggunakan komposisi bahan salut yang sama .

\section{HASIL DAN PEMBAHASAN}

\section{Hasil Uji Viskositas Larutan Pati}

Hasil uji viskositas larutan pati berturutturut adalah untuk pati alam sebesar 8000 cPs, untuk larutan pati termodifikasi enzimatis sebesar $26 \mathrm{cPs}$ dan untuk pati impor yang ada dipasaran adalah $114 \mathrm{cPs}$. Penurunan viskositas pati termodifikasi enzimatis ini disebabkan oleh aktivitas amilase menghidrolisis/mendegradasi pati (amilosa) menjadi suatu produk yang larut dalam air yaitu molekul glukosa dan maltosa. Dengan menurunnya viskositas larutan pati termodifikasi enzimatis ini dapat memudahkan campuran salut terdispersi dan terdistribusi pada kertas dasar salut sehingga dapat meningkatkan daya rekat antara pigmen dengan kertas dasarnya (Werner, 2006).

\section{Pengujian Lembaran Kertas Salut}

Lembaran kertas cetak salut yang dihasilkan dari laboratorium BBPK maupun dari Industri kertas, kemudiaan diuji. Pengujian lembaran terdiri dari derajat putih, kekasaran, penetrasi minyak, ketahanan cabut (IGT), daya serap air $\left(\mathrm{Cobb}_{60}\right)$, dan $\mathrm{pH}$. Hasil pengujian lembaran kertas salut dapat dilihat pada Tabel 2.

\section{Derajat Putih}

Derajat putih didefinisikan sebagai perbandingan antara intensitas cahaya biru dengan panjang gelombang $457 \mathrm{~nm}$ yang dipantulkan oleh permukaan kertas atau karton dengan pencahayaan baur dengan sudut pengamatan $0^{\circ}$, dinyatakan dalam \%. Pigmen sangat mempengaruhi derajat puth kertas, pigmen berwarna pengaruhnya sama dengan pengaruh zat warna terhadap kertas. Selain pigmen beberapa jenis bahan pengisi mengakibatkan perbedaan derajat putih antara kedua permukaan karena bahan pengisi cenderung terkumpul dipermukaan kertas. Dari hasil pengujian diatas nilai derajat putih untuk blanko, variasi 1 (pati alam), variasi 2 (pati termodifikasi enzimatis) dan variasi 3 (pati impor) diperoleh masing-masing 
Tabel 2. Hasil Pengujiaan Lembaran Kertas Salut

\begin{tabular}{llccccc}
\hline No. & \multicolumn{1}{c}{ Parameter } & Satuan & Blanko & $\begin{array}{c}\text { Pati Alam } \\
\text { (Variasi 1) }\end{array}$ & $\begin{array}{c}\text { Pati Termodifikasi } \\
\text { Enzimatis (Variasi 2) }\end{array}$ & $\begin{array}{c}\text { Pati Impor/ } \\
\text { Komersial } \\
\text { (Variasi 3) }\end{array}$ \\
\hline 1. & Derajat Putih & $\%$ & 76,0 & 79,0 & 81,0 & 79,0 \\
2. & Kekasaran & $\mathrm{mL} / \mathrm{menit}$ & 800 & 700 & 600 & 700 \\
3. & Penetrasi Minyak & $1000 / \mathrm{mm}$ & 40 & 26 & 21 & 25 \\
4. & Ketahanan Cabut (IGT) & $\mathrm{Pm} / \mathrm{s}$ & 164 & 335 & 432 & 357 \\
5. & Cobb & $\mathrm{g} / \mathrm{m}^{2}$ & 138 & 113 & 78 & 90 \\
6. & $\mathrm{pH}$ & 6,8 & 6,9 & 7,0 & 6,9 \\
\hline
\end{tabular}

adalah $76 \%, 79 \%, 81 \%$, dan $79 \%$. Penggunaan pati termodifikasi enzimatis dapat merekatkan pigmen lebih banyak sehingga nilai derajat putihnya menjadi lebih tinggi. Pengaruh jenis pati terhadap derajat putih lembaran dapat dilihat pada Gambar 4.

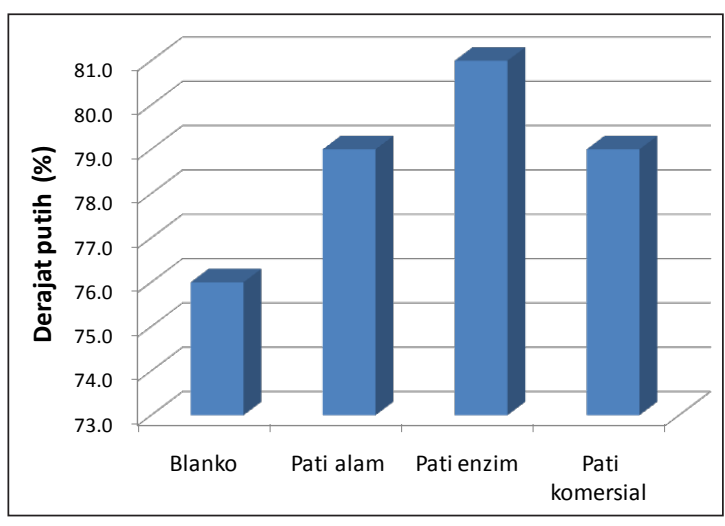

Gambar 4. Pengaruh Jenis Pati terhadap Derajat Putih Lembaran

\section{Kekasaran}

Kekasaran adalah jumlah milliliter udara per satuan waktu yang dapat melalui celah-celah antara permukaan kertas atau karton dengan lingkaran pelat logam yang diletakkan diatasnya, diukur pada kondisi standar. Kekasaran ini penting untuk kertas cetak karena mempengaruhi kualitas hasil cetakan dan tingkat penyerapan tinta. Kekasaran lembaran dikendalikan oleh jenis dan struktur serat serta komponen lain seperti bahan pengisi, proses salut, proses pendarihan permukaan serta formasi lembaran dan tingkat konsolidasi serat melalui proses pengempaan dan calendering (Smook, 2002). Pada Tabel 2, terlihat untuk blanko, variasi 1 (pati alam), variasi 2 (pati termodifikasi enzimatis) dan variasi 3 (pati import) masing-masing diperoleh nilai kekasaran adalah $800 \mathrm{~mL} / \mathrm{menit}, 700 \mathrm{~mL} / \mathrm{menit}, 600 \mathrm{~mL} /$ menit, dan $700 \mathrm{~mL} / \mathrm{menit}$.

Pengaruh jenis pati terhadap kekasaran lembaran dapat dilihat pada Gambar 5.

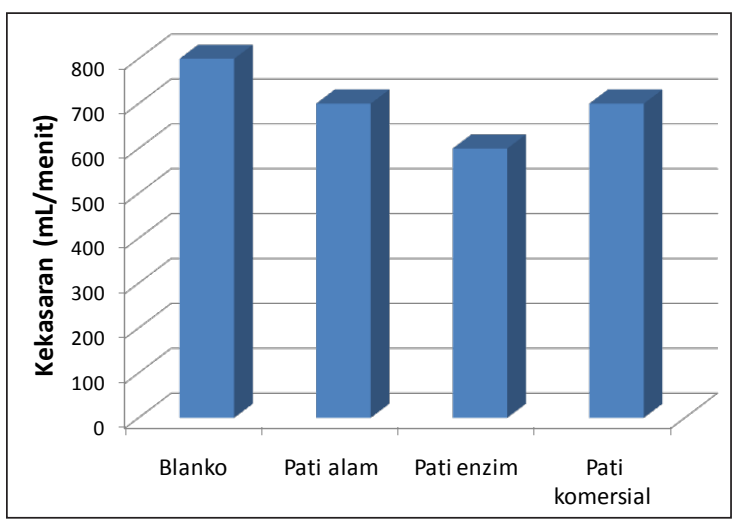

Gambar 5. Pengaruh Jenis Pati terhadap Kekasaran Lembaran

\section{Penetrasi Minyak}

Penetrasi minyak didefinisikan sebagai besaran yang menyatakan sifat penyerapan kertas dan karton terhadap zat cair standar, dihitung berdasarkan kebalikan panjang hasil cetakan pada jalur uji, dinyatakan dalam satuan 1000/ $\mathrm{mm}$, diukur menggunakan alat uji cetak IGT pada kondisi standar. Salah satu faktor penting dari kertas salut untuk dapat mengalami proses cetak yang baik adalah kemampuan menerima tinta dan menyerap tinta yang dipengaruhi oleh pemakaian jumlah perekat. Jenis-jenis pigmen seperti kalsium karbonat terendapkan dan kaolin 
yang mengalami pemanasan meningkatkan penyerapan tinta (Werner, 2006).

Dari hasil pengujian penetrasi minyak untuk blanko, variasi 1 (pati alam), variasi 2 (pati termodifikasi enzimatis) dan variasi 3 (pati import) masing-masing diperoleh sebesar 40, 25, 21 dan 26 dengan satuan 1000/mm. Pemakaian pati termodifikasi enzimatis sebagai perekat menghasilkan nilai penetrasi minyak yang paling baik dibandingkan dengan pati alam maupun pati import. Hal ini disebabkan karena pati termodifikasi enzimatis mempunyai viskositas yang rendah sehingga pati termodifikasi enzimatis tersebut yang fungsinya sebagai perekat dapat terdispersi dan terdistribusi dengan merata pada lembaran kertas yang dihasilkan. Pengaruh jenis pati terhadap penetrasi minyak lembaran dapat dilihat pada Gambar 6 sebagai berikut :

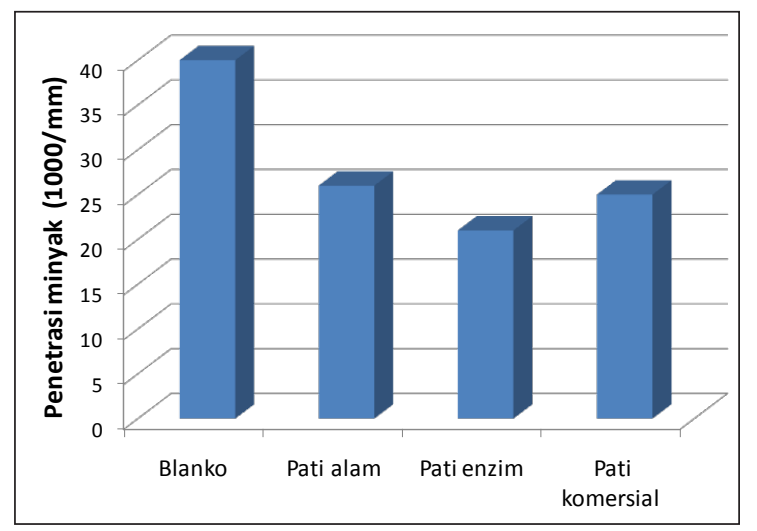

Gambar 6. Pengaruh Jenis Pati terhadap Penetrasi Minyak Lembaran

\section{Ketahanan Cabut}

Ketahanan cabut sangat dipengaruhi oleh jumlah penggunaan perekat dan distribusinya pada kertas. Dari hasil pengujiaan diperoleh nilai ketahanan cabut untuk blanko adalah sebesar $164 \mathrm{Pm} / \mathrm{s}$, variasi 1 (pati alam) sebesar $335 \mathrm{Pm} / \mathrm{s}$, variasi 2 (pati termodifikasi enzimatis) sebesar 432 $\mathrm{Pm} / \mathrm{s}$ dan variasi 3 (pati impor) sebesar $357 \mathrm{Pm} / \mathrm{s}$.

Pemakaian pati termodifikasi enzimatis sebagai perekat menghasilkan nilai ketahanan cabut yang paling baik dibandingkan dengan pati alam maupun pati impor. Hal ini disebabkan karena pati termodifikasi enzimatis mempunyai viskositas yang rendah, sehingga penggunaan pati termodifikasi enzim dapat terdispersi dan terdistribusi dengan merata dan juga pati termodifikasi enzimatisatis mempunyai daya rekat yang lebih baik dibandingkan pati alam maupun pati impor (Holik, and Y V Sood dkk., 2010). Pengaruh jenis pati terhadap Ketahanan Cabut lembaran dapat dilihat pada Gambar 7.

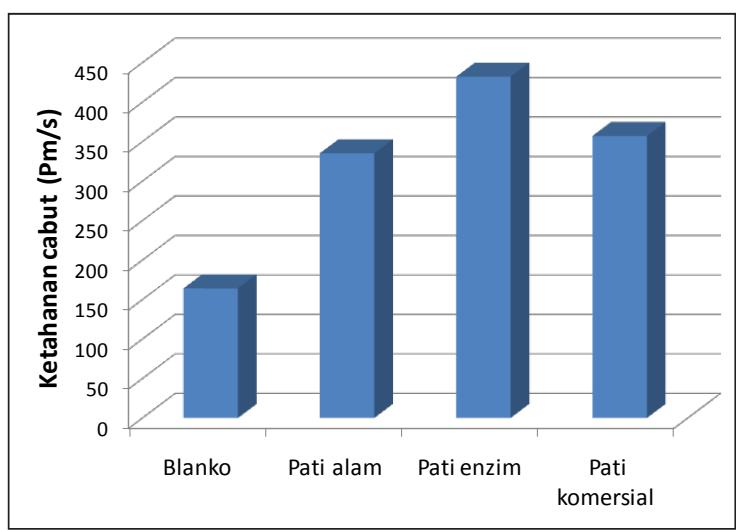

Gambar 7. Pengaruh Jenis Pati terhadap Ketahanan Cabut Lembaran

\section{Daya Serap Air}

Daya serap air $\left(\mathrm{Cobb}_{60}\right)$ adalah jumlah gram air yang diserap oleh $1 \mathrm{~m}^{2}$ lembaran kertas atau karton dalam waktu 60 detik, diukur pada kondisi standar. Semakin kecil nilai daya serap air, maka semakin tinggi daya tahan lembaran untuk menahan penetrasi cairan. Daya serap air merupakan salah satu faktor cukup penting dalam penggunaan kertas tulis maupun kertas cetak. Dari data diatas dapat dilihat bahwa nilai daya serap untuk pati alam adalah $113 \mathrm{~g} / \mathrm{m}^{2}$, untuk pati termodifikasi enzimatis adalah $78 \mathrm{~g} / \mathrm{m}^{2}$ dan pati impor adalah $90 \mathrm{~g} / \mathrm{m}^{2}$, Pengaruh jenis pati terhadap daya serap air $\left(\mathrm{Cobb}_{60}\right)$ lembaran dapat dilihat pada Gambar 8 .

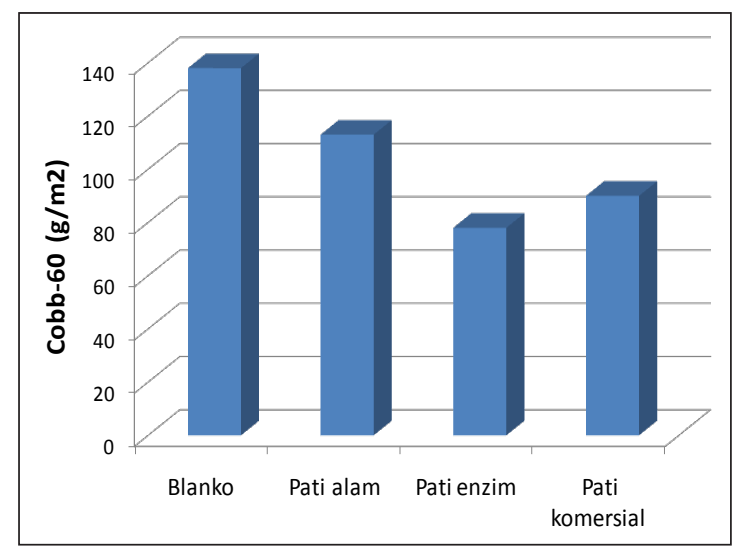

Gambar 8. Pengaruh Jenis Pati terhadap Daya Serap Air Lembaran 
pH

pH kertas didefinisikan sebagai logaritma negatif konsentrasi ion hidrogen dalam larutan ekstrak kertas diukur pada konsisi standar. Nilai pH dapat menjelaskan permanensi kertas secara lebih baik. Bagi kertas-kertas yang digunakan untuk waktu yang sangat lama, sangat penting dan merupakan sifat utama. Dari hasil pengujian $\mathrm{pH}$ untuk blanko adalah sebesar 6,8, variasi 1 (pati alam) sebesar 6,9, variasi 2 (pati termodifikasi enzimatis) sebesar 7,0 dan variasi 3 (pati import) sebesar 6,9.

Pengaruh jenis pati terhadap $\mathrm{pH}$ lembaran dapat dilihat pada Gambar 9.

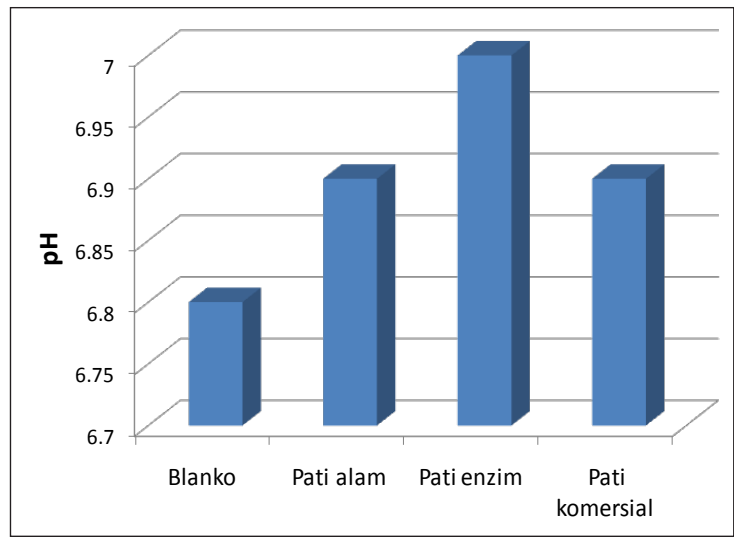

Gambar 9. Pengaruh Jenis Pati terhadap $\mathrm{pH}$ Lembaran

\section{Hasil Pengujian Lembaran Kertas Salut yang dilakukan dari Industri Kertas}

Hasil pengujian lembaran kertas salut yang dilakukan di industri kertas dapat dilihat berikut Tabel 3 .

\section{Derajat Putih}

Nilai derajat putih untuk pati alam, pati termodifikasi enzimatis dan pati impor masingmasing adalah sebesar $80,0 \%, 81,0 \%$ dan $80,81 \%$, Nilai derajat putih yang paling tinggi diperoleh pada penggunaan pati termodifikasi enzimatis, hal ini disebabkan karena pati termodifikasi enzimatis dapat merekatkan kalsium karbonat lebih banyak dan terdispersi dengan merata kepada kertas dasar sehingga mengakibatkan nilai derajat putih menjadi lebih tinggi.

\section{Ketahanan Cabut}

Nilai ketahanan cabut untuk pati alam, pati termodifikasi enzimatis dan pati impor masingmasing adalah sebesar 404,2 Pm/s, 493,5 Pm/s dan 451,2 Pm/s. Pemakaian pati termodifikasi enzimatis sebagai perekat menghasilkan nilai ketahanan cabut yang paling baik dibandingkan dengan pati alam maupun pati impor. Hal ini disebabkan karena pati termodifikasi enzimatis mempunyai viskositas yang rendah sehingga pati termodifikasi enzimatis tersebut yang fungsinya sebagai perekat dapat terdispersi dan terdistribusi dengan merata dan juga pati termodifikasi enzimatis mempunyai daya rekat yang lebih baik dibandingkan pati alam maupun pati impor.

\section{Daya Serap Air $\left(\mathrm{Cobb}_{60}\right)$}

Nilai daya serap $\left(\mathrm{Cobb}_{60}\right)$ untuk pati alam adalah $22,3 \mathrm{~g} / \mathrm{m}^{2}$, untuk pati termodifikasi enzimatis adalah $20,8 \mathrm{~g} / \mathrm{m}^{2}$ dan pati impor adalah $21,7 \mathrm{~g} / \mathrm{m}^{2}$. Semakin kecil nilai daya serap air, maka semakin tinggi daya tahan lembaran untuk menahan penetrasi cairan. Daya serap air

Tabel 3. Hasil Pengujiaan Lembaran Kertas Salut

\begin{tabular}{clcccc}
\hline No. & Parameter uji & Satuan & Pati Alam & $\begin{array}{c}\text { Pati Termodifikasi } \\
\text { Enzimatis }\end{array}$ & Pati Komersial \\
\hline 1. & Derajat Putih & $\%$ & 80,0 & 81,0 & 80,81 \\
2. & Ketahanan Cabut & $\mathrm{Pm} / \mathrm{s}$ & 404,2 & 493,5 & 451,2 \\
3. & Cobb $_{60}$ & $\mathrm{~g} / \mathrm{m}^{2}$ & 22,3 & 20,8 & 21,7 \\
\hline
\end{tabular}


merupakan salah satu faktor cukup penting dalam penggunaan kertas tulis maupun kertas cetak. Daya tahan penentrasi cairan yang paling baik diperoleh dengan pemambahan pati termodifikasi enzimatis dibandingkan dengan pati alam maupun pati impor.

\section{KESIMPULAN}

Dari hasil penelitian dapat disimpulkan halhal sebagai berikut;

1. Hasil analisis viskositas untuk larutan pati alam diperoleh nilai sebesar $8000 \mathrm{cPs}$, sedangkan untuk larutan pati termodifikasi enzimatis dan pati komersial masing-masing nilainya adalah sebesar $26 \mathrm{cPs}$ dan $114 \mathrm{cPs}$.

2. Nilai derajat putih, kekasaran, penetrasi minyak, ketahanan cabut, daya serap air dan $\mathrm{pH}$ untuk pati termodifikasi enzimatis lebih baik dibandingkan dengan pati alam maupun pati komersial.

3. Hasil aplikasi di industri kertas untuk pati termodifikasi enzimatis menghasilkan nilai derajat putih, ketahanan cabut dan daya serap air lebih baik dibandingkan pati alam maupun pati komersial.

\section{DAFTAR PUSTAKA}

Holik, H., 2006, Handbook of Paper and Board, Wiley-VCH Verlag GmbH \& Co, Weinheim.

Lehtinen, E. 2000., Pigment coating and Surface Sizing of Paper, Papermaking Science and Technology, Finnish Paper Engineers Association and TAPPI, Fapet Oy, Findland.

Mueller, K., 2005, The Future Role of Mineral Additives in improve Company Margins - Pulp \& Paper Chemicals Outlook, New Orleans, LA.

Ragnarsson, M., 2008, Effect of the partial replacement of SB Latex with Dextrin Starch on the thickness distribution of coating layer, TAPPI ADVANCED Coating Fundamentals Symposium Proceedings, Montreal, Canada

Smook, G A., 2002, Handbook for pulp and paper technologist. $3^{\text {rd }}$ edition, Angus wilde publication, Vancouver, Canada.

Werner Kogler, 2006, Coating of Paper and Board. Handbook of Paper and Board, Wiley-VCH Verlag GmbH \& Co, Weinheim.

Y V Sood, Sanjay T., Renu T., PC Pande \& Rajnish T., Effect of Base Paper Characteristics on Coated Paper Quality, Indian Journal of Chemical Technology, Vol. 17, July 2010, pp. $309-316$ 